W10-7

新生児センター入院症例における紹介元 からみた医療連携の重要性の検討

愛知県コロニ一中央病院小児外科

飯尾賢治，長晊昌宏，加藤純爾，新美教弘，田中修一

【目的】小児医療の中でも新生児救急医療は特殊な疾患 が多く，小児外科医は小児科医のみならず産科医との連 携も重要となる。新生児外科救急疾患で当院新生児セン ターに入院した症例を紹介元から検討した。【方法】2000 年 1 月から2004年12月までの 5 年間に当院新生児センタ 一に入院した外科症例を紹介元により1)総合病院(小児 科ないし産科) 2)産科 (単科病院ないし) 診療所 3 ) 当 院新生児科 4）外来 5)母体般送の 5 群に分類し, 各疾 患においての頻度を比較検討した。成績]入院総数は348 例でそのうち救急疾患と考えられたものは303例であっ た. 紹介元としては，総合病院からがもっとも多く149例 て，次いで産科診療所109例で，新生児科，外来，母体搬 送からはそれぞれ21例，13例，11例であった。疾患別で は，先天性横隔膜へルニアが48例と最も多く総合病院 29 例，産科診療所11例，母体搬送 8 例で，母体搬送入院例 の多くは本症であった，次いで直腸肛門奇形40例では， 産科診療所が25例で総合病院15例上り多かった。肥厚性 幽門狭窄症は27例て，総合病院12例，外来11例，産科診 療所 4 例と外来からの入院例のほとんどは本症であっ た。先天性食道閉鎖症は23例て，産科診療所12例，総合 病院11例とほほ同数であった。【結論】新生児外科救急医 療においては，特に先天性横隔膜ヘルニアの如くの緊急 疾患では治療成績を向上させるために，産科医との緊密 な連携が必須である。

W10-8 地域中核病院の小児救急医療体制下での 小児科と小児外科との連携一診療協力と臨床研修医教育 体制の強化の考察一

聖マリア病院小児外科"，久留米大学病院小児外科21

鶴知光 ${ }^{11}$, 向野美智子 "), 永吉組子", 宗博子", 赤岩正夫"), 田中芳明21

小児救急医療は危機的状洗であると言われて久しい か，その1次的公口となる小児科医の数は不足し，彼ら の労働条件は改䞳していない。久留米市は福岡県南部に 位置し, 病床数1400の当院が力バーする地域は佐賀県卢 大分県西部，熊本県北部に及ぶ。当院には小児外科ス多 ッフ3人，小照科ス多ッフ7人，新生睍スタッフ6人及 びローデートする臨床研修医が常時 4 人〜 7 人という体 制て24時間 1 次〜 3 次までの小児救急医療行ってい る. 2004 年度の時間外小児受診者数は27.171人でその $83.2 \%$ が小児科・新生児科，1.7\%が小児外科であった。 また平日の準夜・深夜带受診者数は 16314 人 $(60 \%)$, 日祭 日が10857人(40\%)であったが，1日の平均受診者を見て みると平目深夜 11.4 人，平目準夜 43.6 人，日祭日は 24 時 間で159.7人てあった。このような㻴境の中, 小児科と 小児外科が連携強化を図っている内容は1)腹部救急疾 患・外傷の共診必須化，2)小児科・小児外科の垣根をな くす病棟システ么，3)小児外科主導の栄盖管理，4)経 口補液㞠法を普及させ時間外の輸液ライン確保時間を少 なくする，5)特定小児外科疾患に対する小児科殹に对す る意識改革, 6 ) 臨床研修医に対する教育連携 0 徹底, 7 )

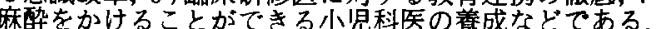
以上，当院のシステムを具体的に紹介しながら，どうす れば合理的で充実した診療が可能か，また地域における 小睍救急医療の問題点・ピットフォール等を考察, 報告 したい.
共VS-1 低位前方切除術の器械吻合におけるIODST の手技と成績

藤田保健衛生大学外科

佐藤美信, 前田耕太郎, 花井恒一, 升森宏次, 小出欣和, 青山浩幸, 勝野秀稔, 船橋益夫, 鎌野俊彰, 安形俊久, 野呂智仁

[はじめに]教室ではより低位の直腸吻合を安全に，さ らに簡便に施行するために1996年よりIO-DSTを導入 してきた。手術体位, 直腸内洗浄法, 自動縫合器挿入法 の土夫とともにその手技と成績を報告寸る。

[手技] 教室では single stapling technique を吻合法の 第一選択とし，これの困難な症例に対してIO-DSTを施

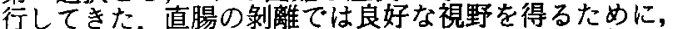
想骨まて十分に皮虚を切開し，大駺水平位，頭高位で手 術を行っている.IO-DSTでは腫瘍直下に鉗子をかけた 後, I 式直腸内洗浄器を用いて1.51 以上の生理食塩水て 直腸内洗净を施行している. Endo GIA60を用いて直腸 を恥骨功尾骨方向に垂直に切断した後, K 式開肛器を 用いて経肛門的に自動縫合器を挿入し，器械吻合を施行 する、リークテストを施行し，人工肛門を造設して手術 を終了する

[成績] IO-DST を施行した下部直腸癌105例を対象と した. 78例で covering colostomy が造設された。これら

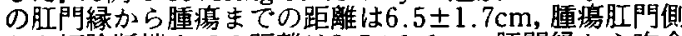

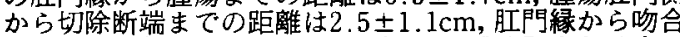
部车での距離は $4.1 \pm 0.9 \mathrm{~cm}$ であった，LAR または人工 肘門閉鎖術 1 月後の排便回数は $4.1 \pm 2.3$ 回/日, LAR 1 年後の排便回数は2.7 1 1.3回/日であった。術後合併症は 縫合不全を 5 例 $(4.8 \%)$, 吻合部狭窄と直腸䐋瘦を各々 1 例（1\%）に認めた。根治度Aの手術を施行した95例中12 例 $(12.6 \%)$ に再発， 3 例 $(3.2 \%)$ に局所再発を認めた。

共VS-2 当科におけるIO-DST 吻合の現況

獨協医科大学第一外科

椿昌裕, 藤田昌紀, 渡辺理, 砂川正勝

器械吻合による直腸癌肛門括約筋温存手術の再建時に用 いる吻合法の一つにIO-DST吻合があり，当科では1998 年10月以降，主に本吻合法による再建を行っている，IO -DST施行時に使用する器材はエンド GIA60mm, PCEEA31mm，パーストリング65mmである．側方郭清 を伴わない全自律神経温存手術術式の概要を記す。下腹 部正中切開で開腹後, 内側アプローチにて大動脈右側の 後腹膜を切開し，次いで尿管下腹筋膜を切開，左右腰内 葴神経，上下腹神経叢を直視同定，温存しながら S 状結 腸を左側に脱転し，外側アプローチに移行して S 状結腸 を完全に遊離. IMA は根部で切断して上方向 D 3 リン 八節郭清を行い，S 状結腸を切断. 両側下腹神経・骨盤神 経灇を温存しながら直腸全周の剥離を行ない，AWを2 $\mathrm{cm}$ 以上確保して直角カンシにて直腸を遮断し，肛門か らイソジン可生理食塩水 $2000 \mathrm{ml}$ にて直腸洗浄を行う.そ の後エンド GIA60mm で直腸を切断し, 口側 S 状結腸断 端にパーストリングを用いて PCEEA31mmのアンビル を装着. 肛門から PCEEA 本体を挿入し，ストレート再 建によるIO-DST 吻合を完成する。これまでの経験では 直腸離断に使用するエンド GIA の本数は 1 〜 本であ る. 現在までに80例の直腸癌に対して IO-DST 吻合を施 行したので, 本セミナーではその治療成績についても報 告する. 
茟VS-3

ダブルスティプリング法を用いた低位結

腸直腸吻合

国立がんセンター中央病院大腸外科

赤須孝之

私どもは直腸癌に対する低位前方切除後の再建に，ダブ ルステイプリング法を用いた低位結腸直腸吻合を行って いる. 吻合に先立ち残存直腸／肛門管をよく洗浄するこ とが重要である。洗浄には生食とイソジンを用いている. 超低位で腸鉗子が不便な場合にはトリプルスティプリン グ法を用いている。これまで吻合部再発は経験していな い. 縫合不全を防ぐためには，吻合部の血流を良好に保 つことが重要である。そのため，以下の点に注意してい る. 1)吻合する結腸に緊張がかからないように十分に剥 離受動する。ただし，左結腸動脈の温存にはこだわらな い.むしろこれを切った方が腸はよく伸びる．2)肛門側 のリニアスティプルの直近をトロカーで穿刺する３） ス テイプリング後の追加縫合は縫合部の血流を妨げるの て，吻合後の追加縫合やリニアステイプル両端の縫合処 理は行わない.さらに，縫合不全予防のために，1）吻 合終了後にはエアーリークテストを行う，2)リークがあ る場合には，補強のための追加縫合を腹腔側または経肛 門的に行い,減圧のための経肛門チューブを挿入したり, covering ileostomy を置く.いずれも基本的なことでは あるが，基本を忠実に守ることにより，縫合不全発生率 を極めて低くすることができる。

共VS-4 我々の行っている直腸低位前方切除術に おける吻合法の工夫

福岡大学医学部第二外科

前川隆文, 山下裕一, 白日高歩

【目的】通常の Double stapling technique に加え, Triple stapling technique やさらに教室で考萫した肛門側直腸断 端举上器具を用いた低位前方切除術の吻合法について報告

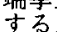

【苸術手技】1.Double stapling technique : 直腸口側を

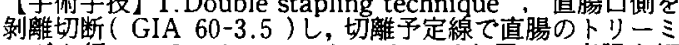
将を行い口テイキュレーター55-4.8を角いて直腸を切 断する。結腸断端のステープルラインにパーストリング65 を掛け第一結热を行いこれを把持しておく．次にメスで切 離しパーストリング65を外し結腸断端を 4 本のアリス錤子 で把持し， $4 \%$ キシロカインを梁布しドワイヤンの腸銝子 を用いて結腸を十分に搪張しアシビルヘッドを挿入しパー ストリング65の縫合系を締め結禁する。次に肛門より EEA 本体を挿入しステープルライン中央, 背側に EEA センター ロッドを乫出させこ机にアンピルヘッドを装着しウイング ナット締め込み後, fireし吻合を完了する. 2. Triple sta-

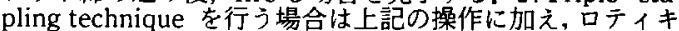
ュレーター30-4.8を用いて直腸右側壁より装着やや中央が 口側に挙上するように掛け次に左側壁上り同様に装着し全 体として逆V字型にfireする。の操作によりロティキュ レーター先端のパンチホールが切除される、3、ロティキュ レーターが操作できない症例に対し肛門側直腸を開放した まま直腸を切断し, 肛門側直腸断端举上器を肛門より挿入 L, Hernia stapler でサージタイを直腸断端に12-16筬所ク リップ固定する。次に EEA 本体を㨉入しサージタイを䋨 め, 口側結腸の宁ンビルヘッドと結合させ吻合を完了する。 【結語】教室で行っている低位前方切除術におりる吻合法 の工夫について報告した。
共VS-5 低位前方切除後の DST 法ートラブルを

避けるために一

国立病院機構大阪医療センター外科

三嶋秀行, 池永雅一, 宮崎道彦, 过仲利政

直腸癌切除後の再建で最も多く行われているのは, DST による端々吻合である.(75\%が DST, 70\%が端々吻合： 大腸疾患外科療法アンケート) 当院では, 以前より側端 吻合（ベーカー法）に準じた手縫いに吻合を行ってきた が, 最近は側端の DST を行っている.2003年 5 月よりの 大腸癌手術 343 例中, LAR は55例であった. 全例 DST て 一時ストマは作成しなかった。 55例中 1 例のみ縫合不全 による直腸胵瘦のため人工肛門を造設した．３例は発熱 により術後 2 日目からの食事を延期したが 3 例とも1週 間後には開始した。吻合トラプルを避けるために，1）血 流と緊張で有利な側端吻合を用いる 2 ) 口側腸管へのへ ッド挿入に要注意 3 ) TMEでない場合は直腸側を断端 から $15 \mathrm{~mm}$ 程度血管処理する．4）直腸は余裕をもって 十分虽離する 5 ) 直腸側はステープルが丈夫な TA45（青ではなく緑）を用いる．低位の場合は TA30(緑)を用いる6) CEEA31を用い,使用説明書を熟 読し器械の特性を熟知する. 組織の厚さは $2 \mathrm{~mm}$ 以下, ウイングナットは最後まで締め，ハンドルはシャフトに つくまで両手でしっかり握ってアンカットを回避する。 TAのピン側や直腸の後壁損傷, 直腸断端など気になる ところがあ机ば吻合前にリークテストや補強を行う。吻 合後は必ずリークテストを行う。アンカットが起こった 場合は，付着側以外の部位を切る，手技の実際を供覧す る.

\section{共VS-6 腹腔鏡下低位前方切除術の吻合法と成縝} 順天堂大学浦安病院外科

福永正氣，木所昭夫，射場敏明，杉山和義，永仮邦彦， 須田健, 吉川征一郎

直腸癌に対する腹腔鏡下低位前方切除術 (LLAR) は視認 性の良さ，繊細な手技が可能であるなどの利点がある反 面, 吻合では難度が高く, 安全, 確実で合併症の少ない 手技が要求される. 現在当科では原則として器械吻合を 採用している. Rs 癌では主に体内で通常 Double Stapling 法(DST) を, Ra 癌では通常 DST または IO-DST を行う。Rb 癌では主にIO-DST を行うが, 深い骨盤底 部の操作であるため直腸洗浄, 肛門側切離ラインの決定, 適切な切離ラインの確保など手技的な問題と確実なスデ ープル形成など技術的な問題がある。これらの解决策と して反転法を利用したDSTや経肛門吻合を症例により 選択している．現在までに腹腔鏡下手術を692例施行し， 直腸癌は169例を経験した。開腹移行は 6 例で移行理由は 他臓器浸潤または疑診 3 例, AW 追加切除のため 1 例な どである。吻合に関連した術中偶発症はDST て EEA 挿 入困難 1 例, AW 追加切除 1 例である。縫合不全は DST 135例中 7 例 $5.2 \%$ である゙特に低位吻合で頻度が高く 改良すべき課題であった。低位直腸で DST が困難な17 症例に反転法を利用し, 体外で TA stapler で切離し，そ の後腹腔鏡下にDST を適応し良好な成績を得ている。 以上, LLAR は手技と技街の進歩にともない安定した吻 合が可能となりつつある. LLAR の問題点を呈示すると ともに手技の工夫について供覧する。 